\title{
ARTICLES
}

\section{DEPRESSION AND ANXIETY AMONG FINAL YEAR B.SC NURSING STUDENTS DURING COVID19 PANDEMIC}

\section{Sr. Ansamma Sebastian (Sr. Alphy SCJG)* | Dr. S. Rajina Rani**}

*Research Scholar, Himalayan University, Itanagar in Arunachal Pradesh, India.

**Research Supervisor, Himalayan University, Itanagar in Arunachal Pradesh, India.

DOI: http://doi.org/10.47211/trr.2021.v07i01.007

\section{ABSTRACT}

Background of the study: COVID-19 virulent disease is the worst pandemic outbreak in the new millennium. This led a way to complete lockdown and created a very bad effect in life of final year students. Depression and anxiety have been recognized as two major health problems in students of final year due to incompletion of their practical section and lag in completing their courses. Aim: To assess the level of depression and anxiety among final year B.Sc. Nursing students. Methods and materials: By using quantitative research design, this descriptive study was conducted in St. John's College of Nursing, Kattappana, Kerala, among 50 pupils, selected using purposive sampling technique. Modified Patient Health Questionnaire was used for assessing the level of depression and Modified State Trait Anxiety Inventory was used to assess the level of anxiety. Results: Among 50 students $8 \%$ presented with mild level of depression, $72 \%$ moderate and $20 \%$ with severe depression. It was also found that equal percentage (50\%) of samples had moderate and severe anxiety.

Key words: Depression, Anxiety, B.Sc. Nursing students, Covid 19 pandemic.

\section{ABOUT AUTHORS:}

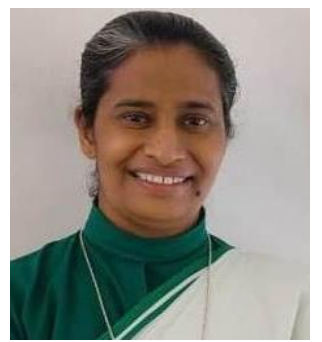

Author Sr. Ansamma Sebastian (Sr. Alphy SCJG) is a Research Scholar in Himalayan University, Itanagar in Arunachal Pradesh, India. She has attended various Seminars and conferences.

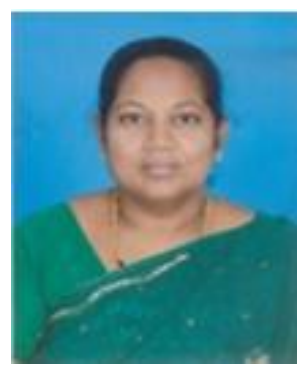

Author Dr. S. Rajina Rani is an active researcher with many publications in her name. She has attended and organised various National and International conferences and has given extensive lectures. At present she is research supervisor, Himalayan University, Itanagar in Arunachal Pradesh, India. 


\section{INTRODUCTION}

\section{"The threat is the virus, not the people".}

\section{-United Nations Foundations}

Covid-19, an infectious disease which threatened the entire world as an impending doom in its commencing period is observed as the worst pandemic that has voyaged. Since the end of last decade, it has paved its path by ostracizing the human being inside the four corners. World governments were forced to formulate and implement stringent measures including wartime protocol to contain its spread.

The implied lockdown measures and exceptions with regards to the same varied from country to country. In India, 55 days of lockdown, initiated from 25 March, 2020 had a drastic effect on the live hood of people. The Indian economy along with others global markets faced a marked recession. Health care, hospitality, tours and travels, IT, recreation, hotels and other sectors were at the verge of an unseen downturn.

Educational Institutions are such a worst hit sector during this pandemic. They were persuaded to modify and adopt distance education for routine learning. Students from kindergarten to post-graduation were obliged to attend classes through the highly advanced online technology. However online era by no means the be-all and end all for practical learning.

Medical and other practice oriented fields cannot solely rely on this platform to carve and furnish its students. No distance learning can inculcate practical experience to students unless exposed with the same. This type of modern education has created a sense of insecurity among the regulators and students of the profession.

In the modern era, practical skills are of utmost importance in machinery and hospitality sectors. A broken machine is replaceable but no man can be displaced with respect to another. Therefore, Medical professionals are obliged to treat and care human beings with critical and efficient adeptness. At the end of their graduate studies, they must sculpt to act promptly to handle any emergencies including life threatening situations.

\section{NEED FOR THE STDUY}

The dynamic world has paused its marathon since March, 2020 and is resting on its wheels. The perennial worlds has seen brink of drought due to COVID-19 disease. Corona virus disease 2019 is an illness caused by severe acute respiratory corona virus 2 (SARS COV-2). This ailment can cause fever, cough, and cold and even has the potential for pneumonia, and death in people with co morbid illness.

The first case was identified in Wuhan, China in December 2019. Afterwards, it spread across continents such as fire. Direct and indirect contact catalyzed the transmission among people. The disease has affected 219 countries and territories around the world with an estimate of 96.63 million cases worldwide. The statistical data shows 69.3 million recovered cases and 2.06 million death throughout the globe.

The scenario has been pervading in the Indian society and the first case was identified in the Kerala state on 30 January, 2020. With regards to the Statistics on 20 January, 2021 a total of 10, 596,442 cases and 15, 2754 were estimated.

Declaration of COVID-19 as a pandemic by WHO in the second week of March, 2020 has persuaded the world powers to freeze the entire trade and commerce irrespective of the foreseen recession. Transmission of the pandemic was curtailed by suspending international travels, closing public spaces, no matter how pivotal they are. Social distaining measures laid a barrier in the educational institutions including school, college and university to recommence learning. They remain closed and governments were confused to disclose an accurate plan regarding the commencement. Both educators and learners abstained from classes, practical and examination. Final year students in schools and colleges got puzzled to determine future endeavor. Reliance on online platforms, physical absence of teachers and classmates, cancellation of examinations, absence of adequate coping strategies are lead to increased stress, anxiety and depression among them.

Depression and anxiety have been recognized by the WHO as two major mental health problems in students during the epidemic. Drastic depression and anxiety were markedly seen in the students especially the final year students.

In terms of Medical education, Nursing students are such highly affected population as this course attributes equal weightage to both clinical and theoretical learning. A question of inadequate clinical experience triggered a change in their mental equilibrium. Sign of increased anxiety, helplessness and hopelessness are pronounced in their behaviours. Therefore the researcher was interested to discover depths of anxiety and depression experienced by final year B.Sc. nursing students in a selected college of nursing in Kattappana. 


\section{STATEMENT OF THE PROBLEM}

"A descriptive study to assess depression and anxiety among final year B.Sc Nursing students during COVID19 pandemic in a selected College of Nursing, Kattappana, Kerala."

\section{OBJECTIVES OF THE STUDY}

$>$ To assess the level of depression and anxiety among final year B.Sc. Nursing students.

$>$ To determine the association between level of depression and baseline proforma

$>$ To demonstrate the association between anxiety and baseline proforma

\section{ASSUMPTIONS}

$>\quad$ Lag in course completion shows increase in level of anxiety.

$>$ Economic instability in family due to pandemic shows increasing level of depression in final B.Sc. nursing students.

$>$ New rules and regulation due to pandemic made the mental status of pupil worst.

\section{REVIEW OF LITRATURE}

A research work was done by Calik, M.(2020) on anxiety level of university students in COVID-19 pandemic. Beck Anxiety Inventory (BAI) and State Trait Anxiety Inventory-1 (STAI-1) were used to collect the data. Result of the study revealed the average score of boys were about 11.56 and girls were 16.65 .

Son, C. (2020) conducted an Interview Survey Study on Consequences of COVID-19 on University scholars mental health. Perceived Stress Scale 10 (PSS-10) was the tool adopted for the study. The study result disclosed that 91\% stated trouble in concentrating, $89 \%$ disturbance in sleeping and $86 \%$ reduced social interaction due to social isolation.

Shete, A.(2015) performed a study among health care students and results of the study showed the depression score about 6.26. Risal, A (2016) proved the depression level of nursing students by using Beck Depression Inventory. The outcome of the study depicts that $40 \%$ of them were suffering from depression. Samson, P. (2020) used a quantitative approach to assess anxiety and depression among 650 nursing students in India. Majority of the students reported high to severe level of anxiety and depression.

\section{MATERIALS AND METHODS}

A Quantitative research approach with descriptive design was used in the study. The setting of the study was in St John's College of nursing, Kattappana, Kerala and 50 B Sc. Nursing students were selected by using purposive sampling technique. Modified Patient Health Questionnaire and Modified State Trait Anxiety Inventory were used to assess the level of depression and anxiety respectively.

\section{RESULTS}

Description of Baseline Proforma.

\begin{tabular}{|c|c|c|c|c|c|c|c|}
\hline \multirow[t]{2}{*}{ S.No } & \multirow[t]{2}{*}{ Baseline Proforma } & $\mathbf{F}$ & $\%$ & \multirow[t]{2}{*}{ S no } & \multirow[t]{2}{*}{ Baseline proforma } & $\mathbf{F}$ & $\%$ \\
\hline & & & 50 & & & \multicolumn{2}{|c|}{$\mathrm{n}=50$} \\
\hline 1. & $\begin{array}{l}\text { Age in years } \\
22 \\
23\end{array}$ & $\begin{array}{l}42 \\
8\end{array}$ & $\begin{array}{l}84 \\
16\end{array}$ & 6. & $\begin{array}{l}\text { Education of mother } \\
\text { Up to } 10^{\text {th }} \\
\text { Undergraduates and graduates } \\
\text { Above degree }\end{array}$ & $\begin{array}{l}2 \\
46 \\
2\end{array}$ & $\begin{array}{l}4 \\
92 \\
4\end{array}$ \\
\hline 2. & $\begin{array}{l}\text { Gender } \\
\text { Male } \\
\text { female }\end{array}$ & $\begin{array}{l}1 \\
49\end{array}$ & $\begin{array}{l}2 \\
98\end{array}$ & 7. & $\begin{array}{l}\text { Occupation of father } \\
\text { Govt/Pvt employee } \\
\text { Self-employees } \\
\text { Others }\end{array}$ & $\begin{array}{l}15 \\
21 \\
14\end{array}$ & $\begin{array}{l}30 \\
42 \\
28\end{array}$ \\
\hline 3. & $\begin{array}{l}\text { Religion } \\
\text { Christian } \\
\text { Hindu } \\
\text { Muslim }\end{array}$ & $\begin{array}{l}44 \\
5 \\
1\end{array}$ & $\begin{array}{l}88 \\
10 \\
2\end{array}$ & 8. & $\begin{array}{l}\text { Occupation of mother } \\
\text { Govt/Pvt employee } \\
\text { Self-employees } \\
\text { Others }\end{array}$ & $\begin{array}{l}7 \\
2 \\
41\end{array}$ & $\begin{array}{l}14 \\
4 \\
82\end{array}$ \\
\hline 4. & $\begin{array}{l}\text { Residential area } \\
\text { Urban } \\
\text { Rural }\end{array}$ & $\begin{array}{l}32 \\
18\end{array}$ & $\begin{array}{l}64 \\
36\end{array}$ & 9. & $\begin{array}{l}\text { Family income } \\
<15,000 \\
15,000-30,000 \\
>30,000\end{array}$ & $\begin{array}{l}33 \\
11 \\
6\end{array}$ & $\begin{array}{l}66 \\
22 \\
12\end{array}$ \\
\hline 5. & $\begin{array}{l}\text { Education of father } \\
\text { Up to } 10^{\text {th }} \\
\text { Undergraduates } \\
\text { graduates } \\
\text { Above degree }\end{array}$ & $\begin{array}{l}5 \\
44 \\
1 \\
1\end{array}$ & $\begin{array}{l}10 \\
88 \\
2\end{array}$ & 10. & $\begin{array}{l}\text { Mode of stay } \\
\text { Day scholars } \\
\text { Hostellers }\end{array}$ & $\begin{array}{l}8 \\
42\end{array}$ & $\begin{array}{l}16 \\
84\end{array}$ \\
\hline
\end{tabular}




\section{ARTICLES}

Assessment of the level of depression among final year B.Sc. nursing students.

\section{Level of Depression}

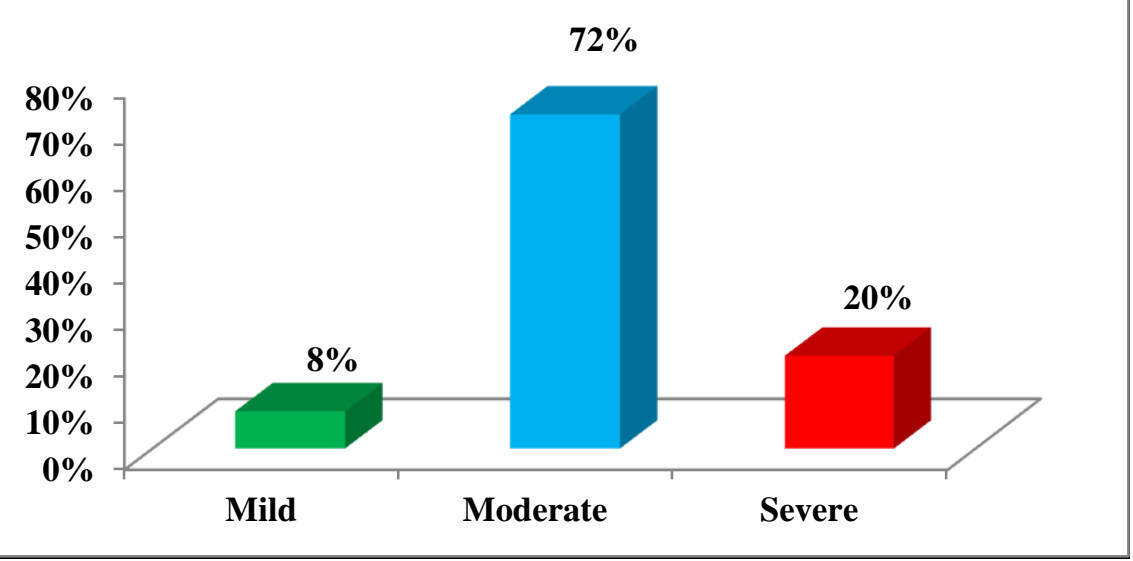

Assessment of the level of anxiety among final year B.Sc. nursing students.

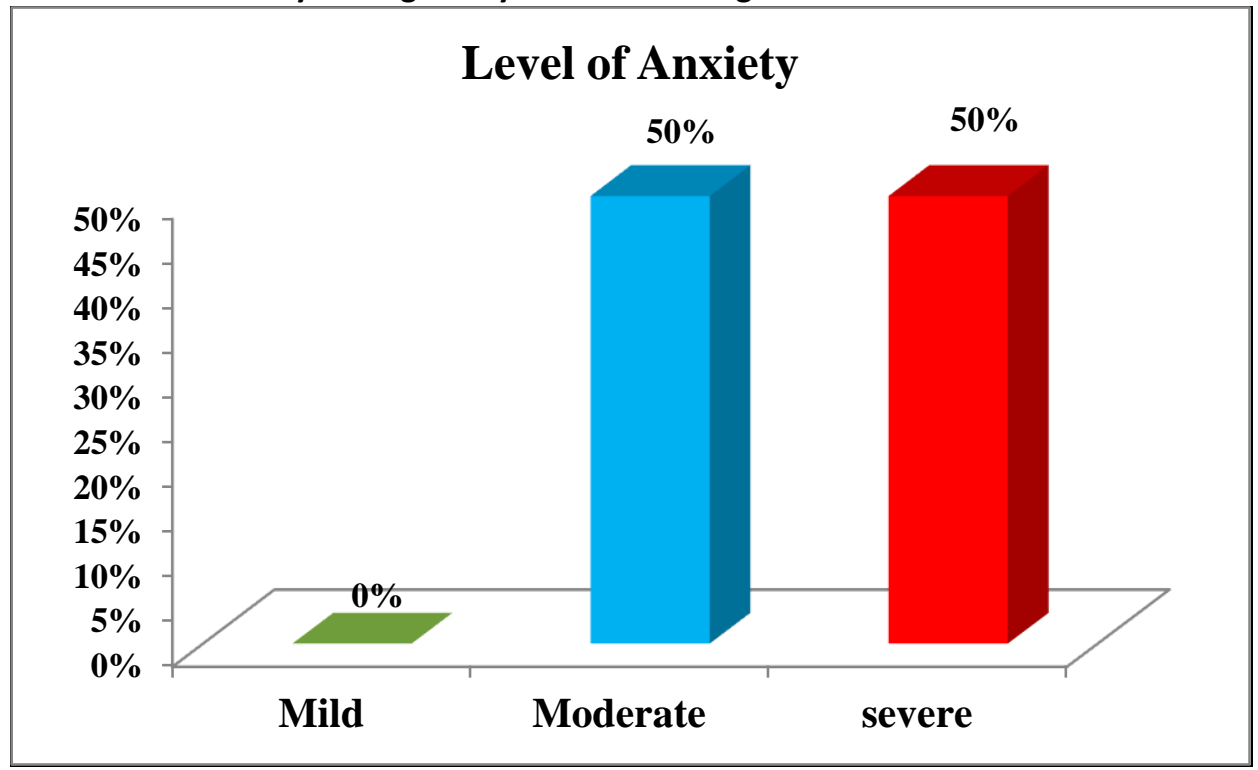

Mean and SD of Depression and Anxiety scores

\begin{tabular}{|l|l|l|l|l|l|}
\hline & N & Minimum & Maximum & Mean & Std. deviation \\
\hline Depression score & 50 & 10.00 & 42.00 & 26.60 & 7.088 \\
\hline Anxiety score & 50 & 53.00 & 91.00 & 69.16 & 9.658 \\
\hline
\end{tabular}


Association of depression and anxiety with Baseline proforma

$\mathrm{N}=50$

\begin{tabular}{|c|c|c|c|c|c|c|c|}
\hline \multirow{2}{*}{$\begin{array}{l}\text { Sl. } \\
\text { No }\end{array}$} & \multirow[b]{2}{*}{ Variables } & \multicolumn{3}{|c|}{ Depression } & \multicolumn{3}{|c|}{ Anxiety } \\
\hline & & $\begin{array}{c}\text { Chi } \\
\text { square }\end{array}$ & df & t value & Chi square & $\mathrm{df}$ & t value \\
\hline 1 & Age & 0.479 & 2 & 5.99 & 0.000 & 1 & 3.84 \\
\hline 2 & Gender & 0.397 & 2 & 5.99 & 1.020 & 1 & 3.84 \\
\hline 3 & Religion & 2.030 & 4 & 9.49 & 3.164 & 2 & 5.99 \\
\hline 4 & Residential area & 10.045 & 2 & 5.99 & 0.347 & 1 & 3.84 \\
\hline 5 & Education of father & 13.699 & 4 & 9.49 & 3.164 & 2 & 5.99 \\
\hline 6 & Education of mother & 5.918 & 4 & 9.49 & 0.000 & 2 & 5.99 \\
\hline 7 & Occupation of father & 3.270 & 4 & 9.49 & 2.857 & 2 & 5.99 \\
\hline 8 & $\begin{array}{l}\text { Occupation of } \\
\text { mother }\end{array}$ & 4.620 & 4 & 9.49 & 2.167 & 2 & 5.99 \\
\hline 9 & Family income & 2.466 & 4 & 9.49 & 0.121 & 2 & 5.99 \\
\hline 10 & Mode of stay & 1.348 & 2 & 5.99 & 10.976 & 1 & 3.84 \\
\hline
\end{tabular}

Association of depression with Baseline proforma shows significant association with residential area and education of father. It was also proven that there is an association of anxiety with mode of stay.

\section{DISCUSSION}

In the present study, final year B.Sc. Nursing students are having moderate to severe depression with anxiety. A similar study was done by Rani,M.(2019), she assessed depression among college students in Mangalore. Out of the total participants, $26.6 \%$ had mild, $41.2 \%$ moderate and $11.4 \%$ had severe depression. Another study by Kamberi, M. (2018) performed a study and proved that $41.1 \%$ of college students had mild anxiety level, $24.1 \%$ moderate and $9.5 \%$ revealed severe anxiety level.

\section{CONCLUSION}

COVID - 19 is the most horrible pandemic which affected whole world in different ways. Final year nursing students were experiencing uncertainty for their future due to lag in classes and examinations. This study proved the evidence of depression and anxiety in them and it is important to provide interventions to avoid complications.

\section{REFERENCE}

1. Bhardwaj, R. (2020). A descriptive study to assess depression, anxiety and stress among higher secondary students of Government Schools of Chandigarh, India. Journal of IPHA Chandigarh State Branch Chandigarh. https;//www.researchgate.net/publication/340377078.

2. Son, C. et al (2020).Effect of COVID-19 on College Students Mental Health in this United State : Interveiw Survey study, Journal of Medical Internet Research https://www.ncbi.n/m.nib.gov/PMC/articles/PMC7473.

3. Shete, A. et al (2015). Stress among post graduate Medical Students Aurangabad, India.Chrismed Journal of health and research. https://www.cjhr.org/article-a sp?/ssn=2348334:year=2015: volume=2, issue=2, spage=119, epage123anulastshete.

4. Risal, A. etal. (2016). Study of depression among the nursing student in a university medical college of Nepal.pubmed. https://Pubmed.nebi.n/m.nib.grv/28814691/

5. Samson, P. (2020). Effect of Perceived Social Support on Stress, Anxiety and Depression among Nepalese Students. Indian Journal of Continuing Nursing Education. 59-63. 